\title{
CD72 Gene
}

National Cancer Institute

\section{Source}

National Cancer Institute. CD72 Gene. NCI Thesaurus. Code C21166.

This gene plays a role in signal transduction that leads to B-cell differentiation. 